\title{
Early Dorset in the High Arctic: A Report from Karluk Island, N.W.T.
}

\author{
JAMES W. HELMER'
}

\begin{abstract}
RÉSUMÉ. Pendant les mois de Juillet et Août 1978 un programme de fouilles archeologiques se realisait sur l'ile de Karluk dans le region du detroit de Crozier (Arctique Septentrional). Le but était de recuperer suffisamment d'échantillons d'artefactes pour imposer des comparaisons inter-regionales et obtenir des données subordonnées et se rattachant à des types de structure, à des modes de subsistance et des données d'occupation saisoniére. Sur tout les systemes de grandes terrasses, en bordure de plage, il est evident qu'il y a eu occupation humaine, cela à des altitudes de 2 à 23 mètres, pendant environ 4000 ans de prehistoire correspondant à l'époque de Thule, celle des outils arctiques en pierre. Des vestiges d'age Dorset précoce se situent sur des plages anciennes, actuellement à une altitude de 8 à 12 métres. On a decourvert 7 sites sur l'ile de Karluk dont 6 sur la cote ouest. Malgré le printemps tardif, les objectifs de recherche étaient largement atteints en 1978. Dans 8 emplacements fouillés, 892 artefactes étaient inventoriés, 41 étaient recuperés de 5 types; 1300 fragments d'os d'animaux étaient ramassés (phoque, morse, caribou, boeuf musque, renard arctique, lemming et plongeur arctique). Les sites les plus voisins d'aspect sont celui de la culture d'Independence 2, d'affiliation Pre Dorset tardif et d'autres d'age Dorset précoce, sont de 3000 à 2500 ans avant notre ere.

Des comparaisons du materiel peuvent se faire avec celui de l'Arctique central, à partir des sites de l'ile de Victoria, d'age Dorset precoce à moyen, en continuité, et aussi avec l'Arctique oriental (site de Tyara). Deux datations au carbone 14, à partir d'os de boeuf musqué de l'ile de Karluk, d'age Dorset précoce, donnent un age de $2205 \pm 120$ ans avant notre ere $2995 \pm 70$ ans à partir de bois flotté.

Les considerations ecologiques et la hauteur relative du site suggerent que cette dernière datation est d'age trop ancien. L'age calculé est celui de bois et non celui du site. L'autre datation est acceptable. Ces decouvertes etendent vers le nord d'environ 600 kilometres l'aire d'extension de la civilisation Dorset précoce et comble un creneau chronologique et typologique de la séquence de l'Arctique septentrional. Il y a deux hypothéses au sujet de l'occupation Dorset précoce dans la region du detroit de Crozier, celle d'un temoin de migration, hors de l'Arctique de centre-est, ou celle d'une occupation permanente dans l'Archipel arctique. L'auteur pense que la seconde hypothése parait plus plausible.

Traduit par Alain de Vendegies, Aquitaine Co. of Canada Ltd.
\end{abstract}

\section{INTRODUCTION}

During the months of July and August 1978, a programme of archaeological excavations was conducted on Karluk Island in the Crozier Strait region of the Canadian High Arctic. The purpose of this project was to continue the examination, begun in 1977, of a number of early Dorset sites (Schledermann, 1977; 1978a; 1978b; Helmer, 1978a; 1978b). The objectives were to recover a sufficient sample of artifacts to legitimately conduct inter-regional 
comparisons, and to obtain ancillary data pertaining to structure types, subsistence patterns, seasonality and date of occupation. In the following paper, the data obtained during the 1978 season are summarized and the significance of this material to High Arctic prehistory is briefly assessed.

\section{Study Area}

Karluk Island is situated in the middle of Crozier Strait, mid-way betwen Bathurst Island and Little Cornwallis Island (Fig. 1). It is a small island, no more than four $\mathrm{km}$ long by two $\mathrm{km}$ wide. A maximum elevation of $c a .50 \mathrm{~m}$ above sea level (a.s.l.) is reached near its northern end.

The dominant physical feature of Karluk Island is the series of fossil beach ridges on the south and west coasts. Terraces, ranging in elevation from $2-50 \mathrm{~m}$ a.s.l., stretch along these coasts broken only by the remnant spill-way of a land-locked lake and a few intermittent streams.

Evidence of human occupation occurs on virtually all the major terrace systems between $2 \mathrm{~m}$ and $23 \mathrm{~m}$ a.s.l. (Schledermann, 1978b). The documented

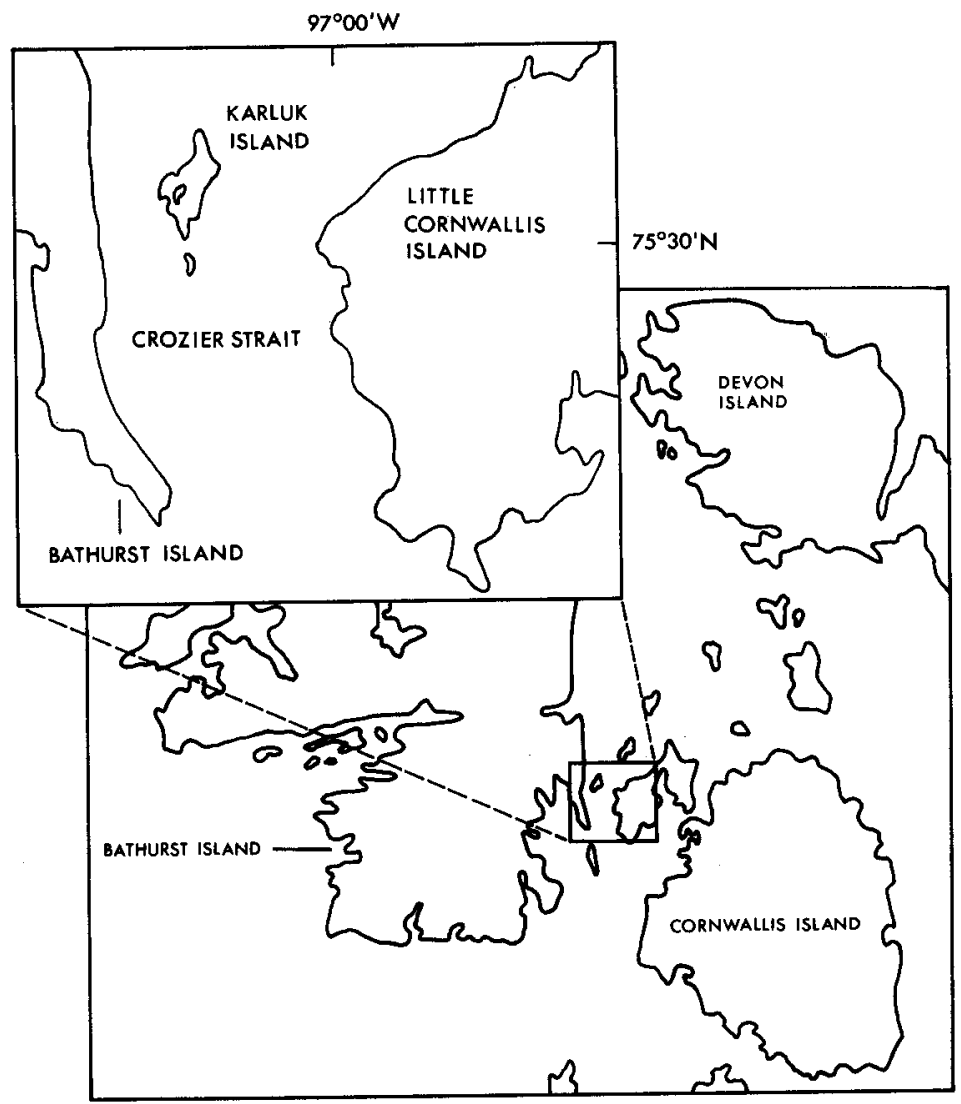

FIG. 1. Study Area. 
sequence embraces approximately 4000 years of prehistory from early Arctic Stone Tool tradition (A.S.T.t.) to Thule Culture times (Schledermann, 1977; 1978a; 1978b). The material remains of the early Dorset occupation of Karluk Island occur on fossil beaches ranging in elevation from $8-12 \mathrm{~m}$ a.s.l.

\section{Site Locality Descriptions}

Seven sites considered to be of early Dorset affiliation were discovered during an initial reconnaissance of Karluk Island conducted by Dr. Peter Schledermann in 1977 (Schledermann, 1977; 1978a; 1978b; Helmer, 1978a; 1978b). Six of these sites are located along the west coast of the island. The seventh site is situated at the south end of the island in a small cove named Polar Bear Bay (Fig. 2).

Each site consists of one or more "find-spots" or "localities". Twenty-four such localities have been identified to date. These features vary widely in composition and include surface scatters of flakes and artifacts, midden-like deposits, isolated hearths and amorphous structures composed of roughly patterned scatters of flat stones.

Six localities, representing five of the seven early Dorset sites on Karluk Island, were excavated during the 1978 season. Two additional localities were

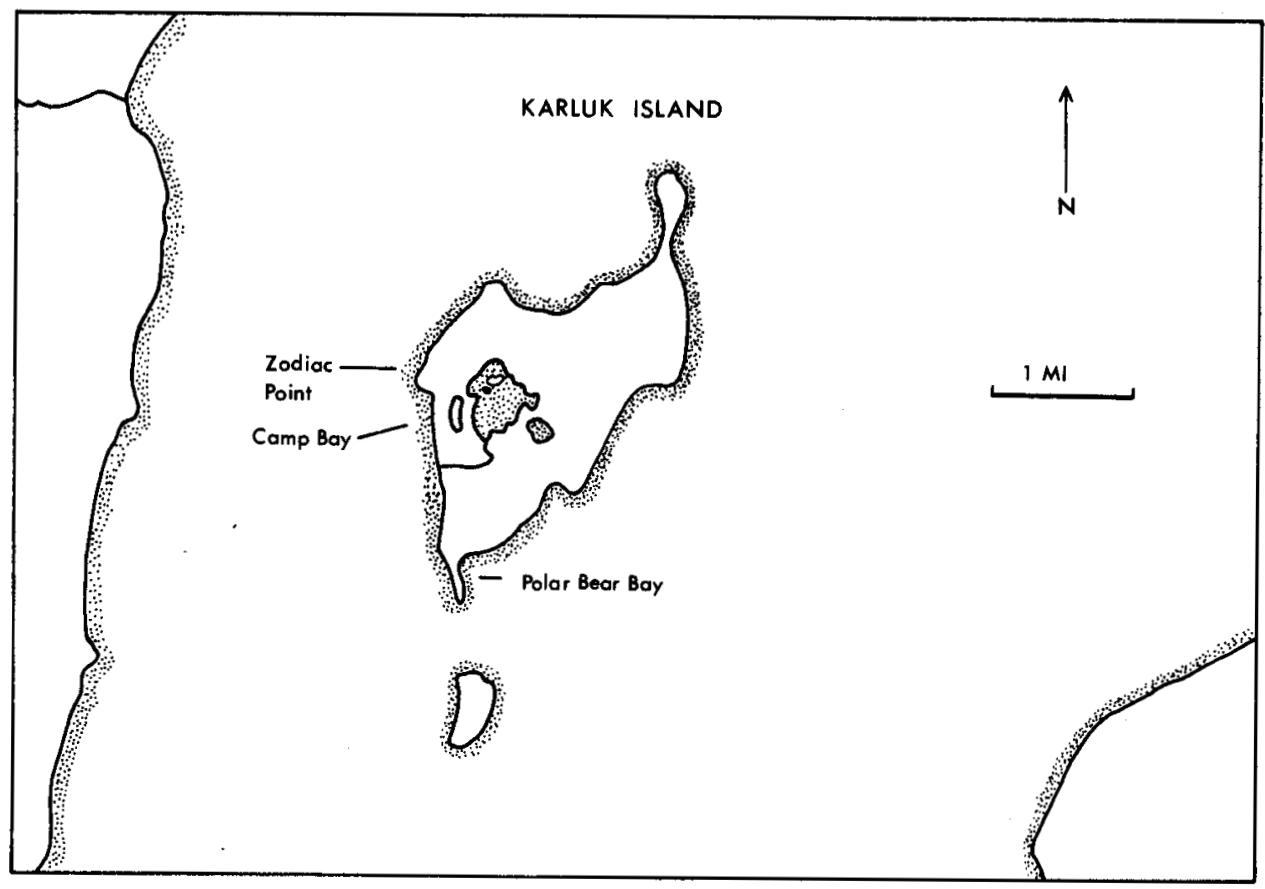

FIG. 2. Karluk Island. 
tested. This sample, (non-statistically derived) covers the range of fossil beach terraces from $8-12 \mathrm{~m}$ a.s.l. and includes at least one example of each of the locality variants described previously.

\section{RESULTS}

A late spring, generally poor weather and early snow in August hampered our excavation programme. However, despite the inclemency of the local climate, the research objectives set for the 1978 season were largely met. The eight localities excavated or tested yielded 892 artifacts, excluding flake cores, utilized flakes and debitage. The various classes of implements found and their relative frequencies of occurrence are summarized in Table 1 (Lithics) and Table 2 (Non-lithic). It should be noted that the categories listed in these tables are largely descriptive and are not meant to be considered "types" in the formal sense.

\section{Artifact Descriptions}

A total of 41 end blades was recovered. Five sub-categories are recognized, including (in order of frequency) side-notched, triangular tip-fluted, multiple side-notched, triangular and asymmetric (Plate 1: a - e). The side-notched category exhibits a wide range of variation. The most common form, however, has narrow side-notches, a triangular blade and a straight or slightly convex base. Features of note in the remaining sub-categories include a preference towards concave bases in both the triangular and the triangular tip-fluted categories, and basal thinning of the majority of the tip-fluted and multiple sidenotched forms.

Bifaces comprise fully $13.5 \%$ of the total collection. Five sub-categories are represented including tip-fluted, parallel sided, leaf-shaped, amorphous and miscellaneous tips (Plate 1: $\mathbf{f}-\mathbf{h}$ ). 


\section{TABLE 1}

Major Tool Types Recovered From Karluk Island Localities: Lithics

\begin{tabular}{|c|c|c|c|c|c|}
\hline Category & Sub-Category & Number & Percent & & \\
\hline End Blades & $\begin{array}{l}\text { Side-Notched } \\
\text { Tip-Fluted } \\
\text { Multiple S-N } \\
\text { Triangular } \\
\text { Assymetric }\end{array}$ & $\begin{array}{r}22 \\
8 \\
6 \\
3 \\
2\end{array}$ & $\begin{array}{l}2.5 \\
0.9 \\
0.7 \\
0.3 \\
0.2\end{array}$ & & \\
\hline Total & & & & 41 & 4.6 \\
\hline Bifaces & $\begin{array}{l}\text { Tip-Fluted } \\
\text { Parallel Sides } \\
\text { Leaf-Shaped } \\
\text { Tips } \\
\text { Amorphous }\end{array}$ & $\begin{array}{l}35 \\
19 \\
23 \\
16 \\
27\end{array}$ & $\begin{array}{l}3.9 \\
2.1 \\
2.6 \\
1.8 \\
3.0\end{array}$ & & \\
\hline Total & & & & 120 & 13.5 \\
\hline Side Blades & $\begin{array}{l}\text { Various } \\
\text { Various }\end{array}$ & $\frac{26}{25}$ & $\frac{2.9}{28}$ & $\frac{26}{25}$ & $\frac{2.9}{28}$ \\
\hline $\begin{array}{l}\text { Scrapers } \\
\text { Burin-Like } \\
\text { Tools }\end{array}$ & $\begin{array}{l}\text { Flaked \& Ground } \\
\text { Angular Tipped } \\
\text { Side-Notched } \\
\text { Misc. }\end{array}$ & $\begin{array}{l}4 \\
3 \\
2 \\
1\end{array}$ & $\begin{array}{l}0.5 \\
0.3 \\
0.2 \\
0.1\end{array}$ & & \\
\hline Total & & & & 10 & 1.1 \\
\hline Abraders & Sandstone & 1 & 0.1 & 1 & 0.1 \\
\hline Vessels & $\begin{array}{l}\text { Sandstone } \\
\text { Biotite }\end{array}$ & $\begin{array}{l}1 \\
2\end{array}$ & $\begin{array}{l}0.1 \\
0.2\end{array}$ & & \\
\hline Total & & & & 3 & 0.3 \\
\hline $\begin{array}{l}\text { Microblade } \\
\text { Cores }\end{array}$ & Various & 5 & 0.6 & 5 & 0.6 \\
\hline Blades & Width $\geqslant 11 \mathrm{~mm}$ & 98 & 10.9 & 98 & 10.9 \\
\hline Microblades & $\begin{array}{l}\text { Proximal/Complete } \\
\text { Fragments }\end{array}$ & $\begin{array}{r}138 \\
79\end{array}$ & $\begin{array}{r}15.5 \\
8.9\end{array}$ & & \\
\hline Total & & & & 217 & 24.3 \\
\hline $\begin{array}{l}\text { Triangular } \\
\text { Microliths }\end{array}$ & Left \& Right Handed & 150 & 16.8 & 150 & 16.8 \\
\hline Total & & & & 696 & 78.0 \\
\hline
\end{tabular}


Table 2

Major Tool Types Recovered From Karluk Island Localities: Organic

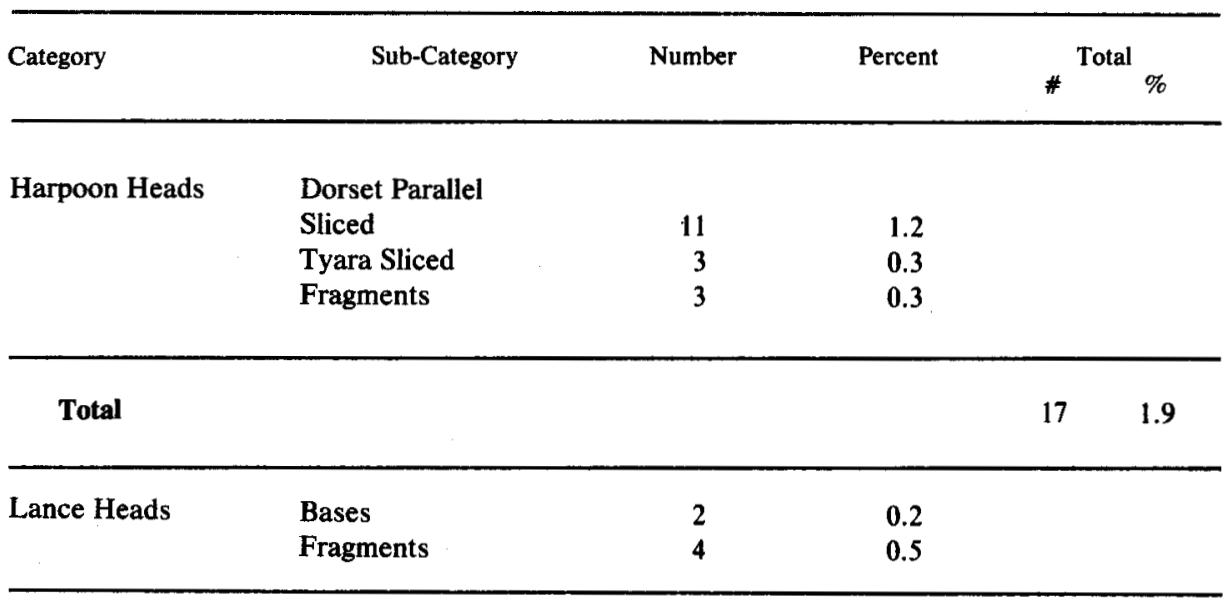

\begin{tabular}{|c|c|c|c|c|c|}
\hline Total & & & & 6 & 0.7 \\
\hline Darts & Multi-Barbed & 3 & 0.3 & 3 & 0.3 \\
\hline Snow Knives & & 6 & 0.7 & 6 & 0.7 \\
\hline Fore Shafts & & 4 & 0.5 & 4 & 0.5 \\
\hline Flakers & Tapered & 7 & 0.8 & 7 & 0.8 \\
\hline $\begin{array}{l}\text { Composite } \\
\text { Handles }\end{array}$ & & 14 & 1.6 & 14 & 1.6 \\
\hline Awls & & 2 & 0.2 & 2 & 0.2 \\
\hline Needles & Dorset Type & 41 & 4.6 & 41 & 4.6 \\
\hline Adze Socket & & 1 & 0.1 & 1 & 0.1 \\
\hline Gorge & & 1 & 0.1 & 1 & 0.1 \\
\hline Ornaments & $\begin{array}{l}\text { Toothed Object } \\
\text { Pendant } \\
\text { Bird Head (?) }\end{array}$ & $\begin{array}{l}1 \\
1 \\
1\end{array}$ & $\begin{array}{l}0.1 \\
0.1 \\
0.1\end{array}$ & & \\
\hline Total & & & & 3 & 0.3 \\
\hline Misc. & Fragments & 91 & 10.2 & 91 & 10.2 \\
\hline Total & & & & 196 & 22.0 \\
\hline
\end{tabular}




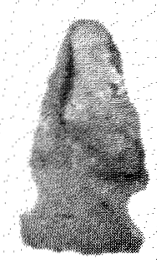

a

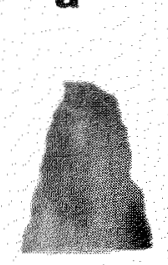

$f$

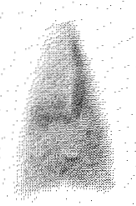

b

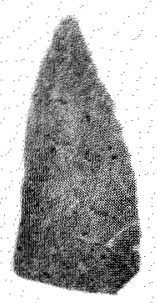

$\mathbf{g}$

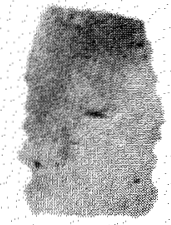

c

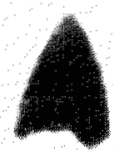

d

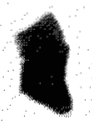

e

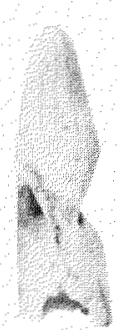

h

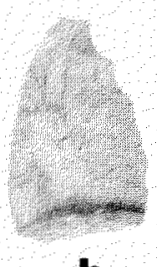

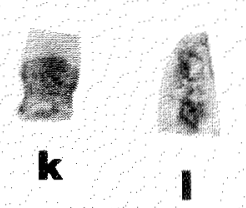

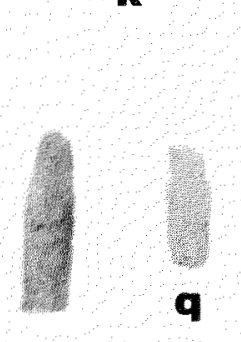

p

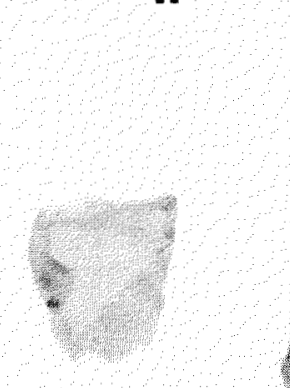

m

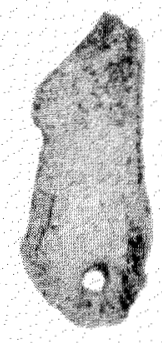

n
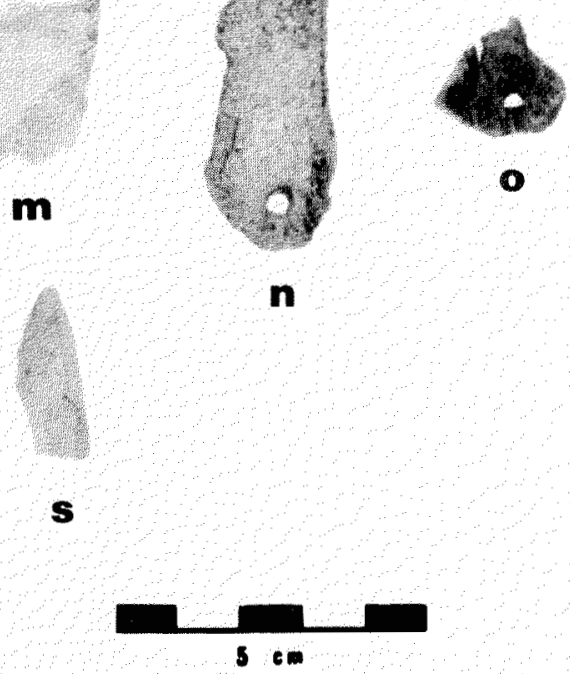

$5 \mathrm{~cm}$

Plate 1. Early Dorset artifacts from Karluk Island: a-e) end blades; f-h) bifaces; i) Dorset Parallel Sliced harpoon head; j) Tyara Sliced harpoon head; k-m) burin-like tools; $\mathrm{n}-\mathrm{o}$ ) lance bases; $\mathrm{p}-\mathrm{r}$ ) microblades; s) triangular microlith.

Three sub-categories of burin-like tools have been identified in the Karluk assemblage: side-notched, angular tipped and crude flaked and ground (Plate 1: $\mathrm{k}-\mathrm{m}$ ). The side-notched and angular tipped forms are relatively common Dorset types. The crude flaked and ground specimens, however, seem to be unique to Karluk Island. 
Microblades are ubiquitous in Dorset assemblages. The distinguishing feature of the Karluk Island microblades is the high frequency of "tanged" proximal ends. At least $50 \%$ of the microblades recovered show fine retouch on opposing edges opposite the bulb of percussion. All the microblades found are well made and relatively narrow (average $6.4 \mathrm{~mm}$ ) (Plate 1: $\mathrm{p}-\mathrm{r}$ ).

Triangular microliths (Collins, 1957: 26) comprise 16.8\% of the total assemblage. Although associated elsewhere with the production of tip-fluted triangular end blades (Meldgaard, 1962: 95), most of the specimens collected are too large to have been struck from such small implements (Plate 1: s). I have successfully fitted a number of these microliths to some of the tip-fluted bifaces and it is likely that the majority are associated with these particular artifacts.

Fragments of three stone vessels were collected (not illustrated). Two different forms are recognizable. One, represented by a number of rim fragments, was probably a small oval vessel with steeply sloping sides. This particular specimen was manufactured from a fine-grained sandstone. The second vessel type is sub-rectangular in outline. The ends are flat and the sides curve gently. The rim is quite thick and is bevelled rather than rounded. Two examples of this vessel form were found; both carved from a soft micaceous rock composed of $90 \%$ biotite (L. V. Hills, pers. comm. 1979).

Fourteen harpoon heads were discovered. The most common form has a transverse line hole, a closed socket with a small v-shaped slice cut into it from the base, a $u$-shaped basal concavity and two bevelled spurs (Plate 1: i). Eleven of these were collected.

Similar harpoon heads have been referred to by Maxwell (1976: 66) as Type IV forms. Taylor (1968: 75) uses the term Dorset Sliced or Dorset Parallel Sliced (cf. Maxwell, 1976: 63). Meldgaard includes similar forms in his Type-state E (Maxwell, 1976: 63).

A second harpoon head type found in the Karluk Island assemblage has a single line hole cut perpendicular to the axis of the socket. The socket itself is closed except for a small v-shaped slice cut into it from the base. The basal concavity is u-shaped and the two basal spurs are bevelled. One specimen has an end blade slot cut perpendicular to the axis of the line hole (Plate 1:j). This harpoon head type is similar to Taylor's (1968: 52) Tyara Sliced and/or Maxwell's (1976: 66) Type II harpoon heads.

Two lance bases were recovered. One specimen (Plate 1:n) is made of antler. It has an indented "waist", an open socket and a single line hole in the base set in a small groove on the dorsal or socket surface. This particular artifact approaches the description that Taylor (1968: 54) gives to his "Pingasuit" lance heads from the Tyara site.

The second lance head is made of ivory (Plate 1: o). It has an open socket, a line hole set in a groove cut in the base and a small notch in the base which intersects with this groove. Two line, or lashing, grooves have been incised into the ventral surface running perpendicular to the axis of the basal groove. This specimen is similar to Taylor's (1968: 53) "Atausik" or "cloven-hoof" lance heads. 
Additional artifact categories worthy of note include snow knives with flat blades of ivory or antler (Plate 2: a), bilaterally barbed darts (Plate 2: b), well formed, tapered flint flakers (Plate 2: c) and a variety of presumed ornamental pieces (Plate 2: $d-f$ ). Examples of the remainder of the artifact inventory from Karluk Island are illustrated in Plate 2: $\mathrm{g}-\mathrm{q}$.
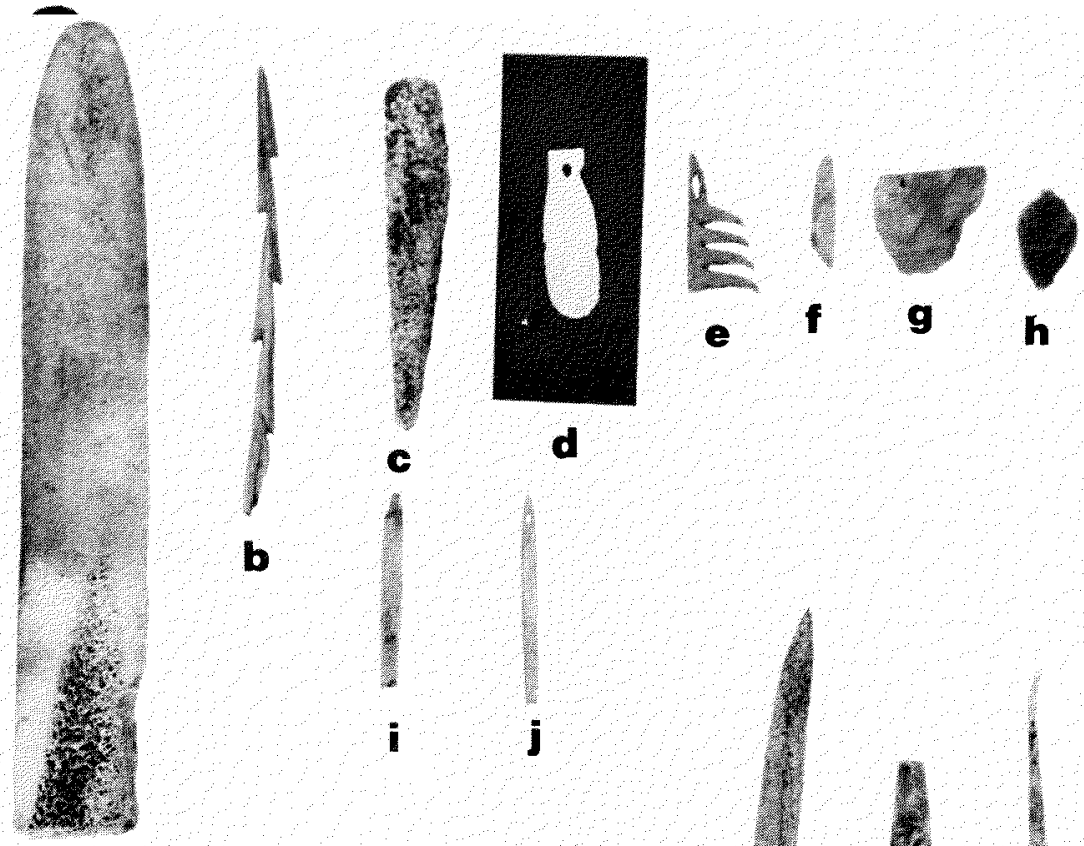

a

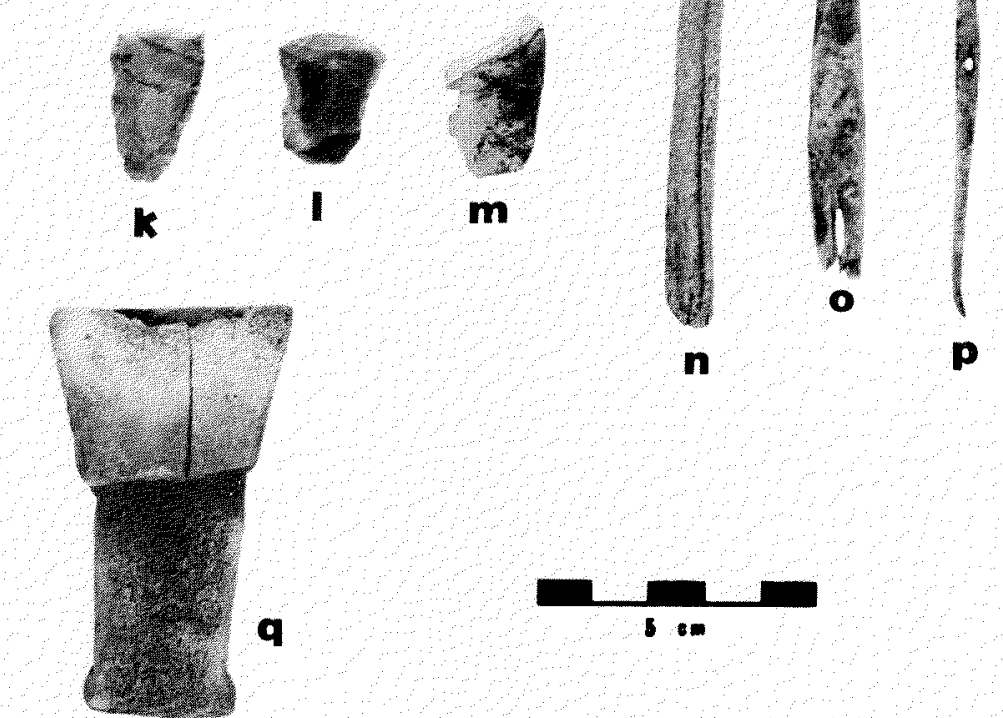

Plate 2. Early Dorset artifacts from Karluk Island: a) knife blade; b) bilaterally barbed dart; c) tapered flint flaker; $d-f$ ) ornaments: $g$-h) side blades; k-1) end scrapers; m) microblade core; n) antler awl; o) foreshaft; p) gorge; q) adze socket. 


\section{Structures}

A number of tent ring features were encountered during our investigations. These structures are all roughly oval in shape and consist of rough scatters of flat limestone slabs and pebbles (Fig. 3). Small hearths, areas of charred fat stain or clusters of fat-stained rocks, occupy central locations within the structures. As a rule, artifact concentrations were confined to the area enclosed by the stone outlines.

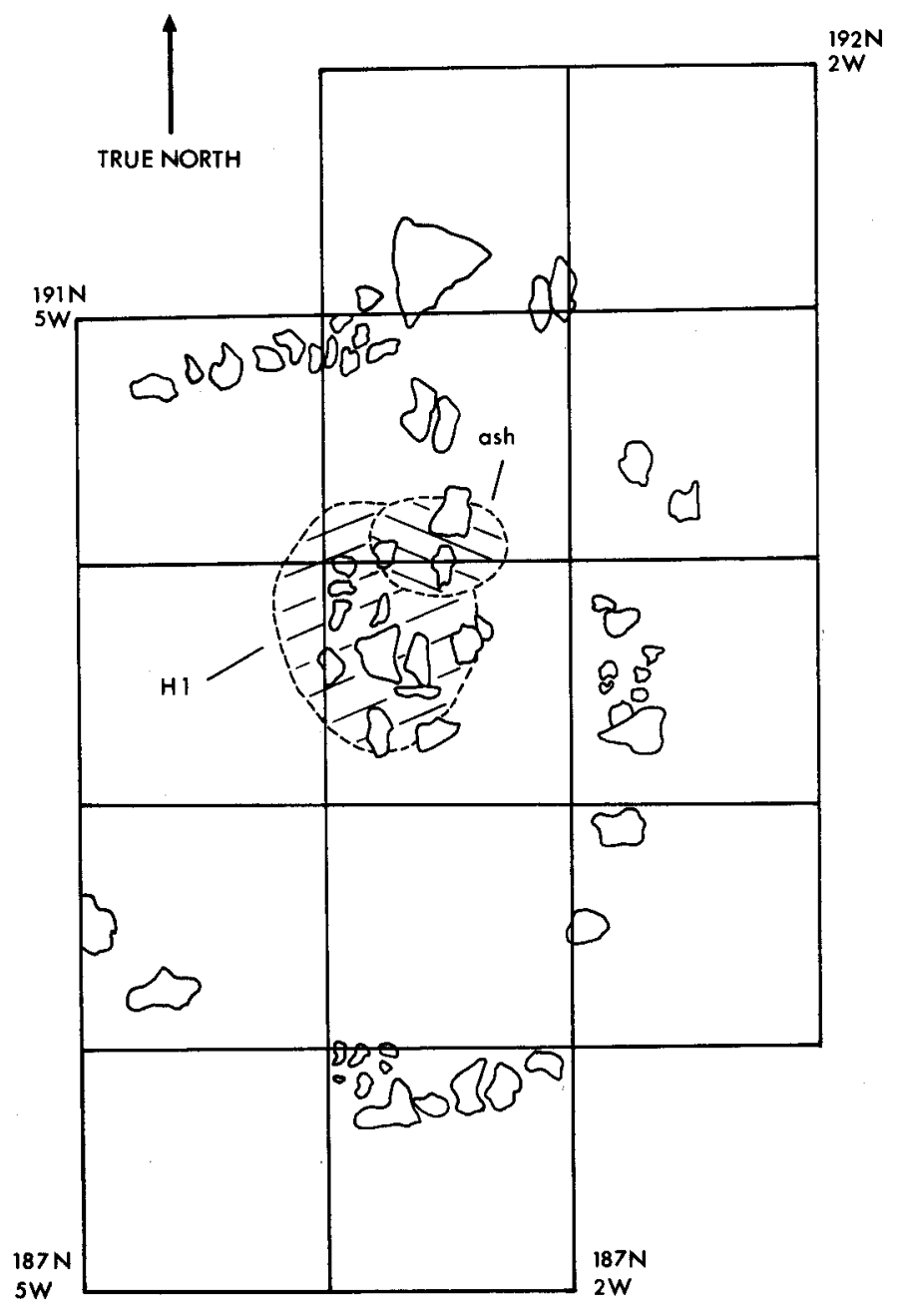

FIG. 3. QjLd-22: tent ring outline.

\section{Faunal Material}

Bone preservation was extremely good in a number of localities. Approximately 1300 bone fragments were collected. Species identified include seal, walrus, caribou, musk-ox, arctic fox, lemming and arctic loon. Seal and walrus bone dominate the assemblage. 
A clue to seasonality is provided by several pieces of fetal ungulate bone. This material, which has been tentatively identified as fetal musk-ox (M. Wilson, pers. comm. 1979), suggest a late winter or early spring occupation as musk-ox calving normally takes place between April and early May (Tener, 1965).

\section{COMPARATIVE ANALYSIS}

Comparison of the Karluk Island assemblage with representative collections from the High Arctic, the Central Arctic and the Eastern Arctic "core-area" allows the following comments.

\section{High Arctic}

Typologically, the High Arctic complex most closely related to the Karluk Island localities is the Independence II culture (Knuth, 1967; 1968; McGhee, $1974 ; 1976 ; 1976$; $1977 ; 1978)$. This is a rather enigmatic complex with some traits indicating a late Pre-Dorset affiliation (Knuth, 1967: 36), and others an early Dorset connection (McGhee, 1976: 27; Schledermann, 1978b: 56). The estimated dates for the Independence II occupation of the Canadian High Arctic range from 3000 to 2500 B.P. (McGhee, 1976: 27).

Independence II sites and the Karluk Island localities share a number of specific traits which indicate some degree of affiliation. Several of the more significant parallels include broadly side-notched end blades, large ovate side blades, flared end scrapers, rectangular vessels and cloven-hoof lance heads (cf. McGhee, 1976; 1978; Knuth, 1967; 1968). The absence of ground slate tools and semi-subterranean house features are negative characteristics also shared by both complexes. However, the occurrence in the Karluk assemblage of such traits as narrow side-notched, triangular tip-fluted and multiple sidenotched end blades, Dorset Parallel sliced and Tyara Sliced harpoon heads and tapered flint flakers, and the fact that no mid-passage structures of the Independence II type have been found on Karluk Island, suggest that these complexes are discrete entities. According to Maxwell's (1976) description of Paleoeskimo harpoon head typology, the harpoon heads found on Karluk Island are more recent forms than those reported from Devon Island (McGhee, 1976: 27) and northeast Greenland (Knuth, 1968: 64-65), indicating that a chronological gap exists between the two groups.

\section{Central Arctic}

Comparative material from the Central Arctic is provided by a number of sites on Victoria Island including the Ballantine, Ferguson, Buchanan and Joss sites (Taylor, 1967; 1972; McGhee, 1971; 1976). A single site from the Bernard Harbour area on the adjacent mainland coast was also included in the comparison (Taylor, 1972). These sites reflect a continuum from early to middle Dorset times. Dates range from $2450 \pm 220$ B.P. (GSC-658) for the Ballantine site to $1860 \pm 100$ B.P. (GaK-1257) for the Joss site (McGhee, 1976: 30). 
The Karluk Island localities and the Central Arctic sites share a large number of traits including, among others, narrow side-notched and tip-fluted end blades, side-notched burin-like tools, small ovate side blades, tapered flint flakers and lance heads of the Pingasuit type. These correspondences suggest a fairly close connection between the two areas. However, the harpoon head types represented in the Central Arctic early/middle Dorset sites (predominantly Type-states A-20 to 22; cf. McGhee, 1976:33) are, typologically, more recent forms than the Dorset Parallel Sliced and Tyara Sliced types recovered from Karluk Island (cf. Maxwell, 1976: 61). The relatively frequent occurrence of tip-fluting and the complete absence of ground slate tools and semi-subterranean house structures in the Karluk inventory reinforce the suggestion that the early to middle Dorset occupation of Victoria Island and the adjacent mainland may have occurred at a slightly later date than the occupation of Karluk Island.

\section{Eastern Arctic}

The Eastern Arctic, specifically the Foxe Basin and Hudson Strait region, is the hypothesized "core-area" of Paleoeskimo culture history (Meldgaard, 1962; Taylor, 1968; Maxwell, 1973; 1976). The early Dorset Tyara, T-1 and Tanfield sites (Taylor, 1968; Collins, 1957; Maxwell, 1973) provide a representative base line for comparative purposes. The Tyara site dates from between $2670 \pm 130$ (GSC 701) and $2200 \pm 130$ (GSC 702) B.P. (Wilmeth, 1978: 29). Dates for the related $T-1$ and Tanfield sites range from $2608 \pm 50$ (P-698) to $2250 \pm 130$ (M-1528) B.P. and from $2632 \pm 128$ (P-76) to $2060 \pm 200$ (P-62) B.P. respectively (Wilmeth, 1978: 28, 51).

Correspondences between the Karluk Island localities and the Tyara, T-1 and Tanfield sites are many. Indeed, with the possible exception of the tip-fluted bifaces and crude flaked and ground burin-like tools, all the artifact categories represented on Karluk Island have counterparts in one or more of these Eastern Arctic early Dorset components.

Absent in the Karluk assemblage are ground slate tools (a predominant characteristic of core-area early Dorset), a rich array of zoomorphic and anthropomorphic carvings, a variety of bone/antler/ivory tools such as sled shoes and needle cases, several harpoon head types, and evidence for the use of true burins (generally a low-frequency trait even in the core-area). Regional variation, differential site function or the vagaries of sampling probably account for the balance of these discrepancies.

Dorset Parallel Sliced and Tyara Sliced harpoon heads, cloven-hoof lance heads, tip-fluted and multiple side-notched end blades have been identified as temporally sensitive "type-fossils" with the Foxe Basin and Hudson Strait region (Linnamae, 1975: 68; McGhee, 1976: 28, 33; Maxwell, 1976: 61-63). The occurrence of these particular artifacts in the High Arctic Karluk Island assemblage argues for close temporal and cultural ties between these two areas.

According to Maxwell (1976: 58), the estimated chronological range of early Dorset in the core-area is $c a .2700$ - 2400 B.P. Corrected according to McGhee and Tuck's (1976: 12) Adjustment II, this should read approximately 2550 - 2300 
B.P. (Maxwell, 1976: 58). On the basis of the preceding comparative analysis, I expect that the temporal parameters of the early Dorset occupation of the Crozier Strait region fall within the latter range.

Subsequent to the initial presentation of this paper, two carbon-14 dates relating to the Karluk Island early Dorset occupation were received (Wilmeth, pers. comm. 1979). A date of $2205 \pm 120$ B.P. (S-1673) was obtained from a sample of unburned musk-ox bone from QjLd-21: 6. A second date of $2995 \pm$ 70 B.P. (S-1674) was run on a charred driftwood sample from QjLd-22:1. Typological considerations and relative height a.s.l. suggest that the latter date is too early. The results of this assay probably describe the age of the driftwood and not the site. The date from QjLd-21: 6 of $2205 \pm 120$ B.P. is, I feel, acceptable as a minimum age for the early Dorset occupation of Karluk Island. It is comparable to the date from level I of the Tyara site $(2200 \pm 130$ B.P. (GSC-702); Taylor, 1968: 107) and to several dates from T-1 and T-3 $(2183 \pm 122$ B.P. [P-74] and $2191 \pm 120$ B.P. [P-77] respectively; Wilmeth, 1978: 51). The date of ca. 2205 B.P. is also statistically in the range of McGhee and Tuck's (1976: 12) adjusted dates for core-area early Dorset (cf. Maxwell 1976: 58).

\section{DISCUSSION}

Prior to 1977, early Dorset per se was unknown north of Lancaster Sound. The 892 artifacts recovered in 1978 indicate that an early Dorset occupation with strong core-area affinities occurred in the Crozier Strait region at some time around ca. 2205 B.P. (uncorrected). This material, therefore, extends the known distribution of early Dorset approximately $600 \mathrm{~km}$ to the northwest and helps fill a chronological and typological gap in the current High Arctic sequence.

Two opposing hypotheses potentially account for the presence of the early Dorset occupation of Karluk Island:

(1) the early Dorset occupation of the Crozier Strait region is the product of a migration out of the eastern Central Arctic; or

(2) the Crozier Strait early Dorset complex is part of an in situ development from Pre-Dorset to Dorset in the Arctic Archipelago.

The current paradigm of Arctic cultural dynamics, the Core Pulsation Model (cf. Fitzhugh, 1974; 1976) or the core-area/periphery dichotomy (cf. McGhee, 1976; 1978; Maxwell, 1976), predisposes one towards acceptance of the former hypothesis. An initial appraisal of the Karluk Island data suggests that migration is, indeed, the more plausible explanation. The assemblages from Karluk Island are, on a typological basis, more similar to eastern Central Arctic early Dorset than they are to Independence II or Central Arctic early to middle Dorset. As corroborative evidence, the available "demographic" data from the High Arctic suggest that the appearance of early Dorset on Karluk Island corresponds to a low point in the site frequency cycle of the Crozier Strait/McDougall Sound region (Schledermann, 1978b: 46-47). Although this latter observation can be interpreted in a number of ways, it may indicate a reoccupation of the area after a period of depopulation (cf. Mcghee, 1976: 27-28). 
The causal mechanism (or mechanisms) for the inferred population movement remains obscure. A number of authors (cf. Fitzhugh, 1974; 1976; Dekin, 1975; McGhee, 1976) have postulated a correlation between warm climatic episodes and population expansion, and between deteriorating climatic conditions and population contractions or extinctions. The early Dorset occupation of Karluk Island at $\mathrm{ca}$. 2205 B.P., however, occurred during a period of pronounced cooling which lasted from ca. 2500 to 2100 B.P. (Barry et al., 1977: 199). A more complex explanation of the hypothesized expansion of early Dorset is obviously required (cf. Barry et al., 1977:200).

It would be theoretically unsound to accept the migration hypothesis without first considering the possibility that an in situ development did occur. Indeed, a few lines of evidence indicate that a case can potentially be made for this alternate hypothesis.

As already noted, there are demonstrable similarities between Independence II assemblages and the Karluk Island early Dorset complex. There is also typological evidence (primarily harpoon head seriation), supported by $\mathrm{C}-14$ dates, which suggests that the Karluk Island material antedates the Independence II occupation by several centuries. These observations reinforce the suggestion made by Schledermann (1978b: 56; 1978c: 473) that Independence II represents a phase which includes late pre-Dorset, transitional and early Dorset culture stages. These observations also indicate that there is a greater degree of occupational continuity in the High Arctic than was previously suspected (cf. Schledermann, 1977: 245; 1978c: 473).

Continuity in a sequence is not synonymous with in situ development. The Core Pulsation Model can still be invoked to account for this phenomenon. However, documentation of sequential occupation is a necessary first step in developing a model of High Arctic prehistory which views in situ development, tempered by trait diffusion and possibly migration, as a viable alternative. An insightful statement by Taylor (1968: 93) concerning the West Greenland culture sequence is especially pertinent in this regard:

"Despite Larsen's reasoned conviction that Dorset replaced Sarqaq as a result of migration into a depopulated area, I think the seriation of the Disko Bay material offers sufficient indication of the possibility of gradual change that one may ask that diffusion and local development also be examined as possible factors in the change."

Given the new data from Karluk Island it becomes conceivable, although by no means conclusive, that a local development from Pre-Dorset to Dorset occurred in the High Arctic with Independence II representing the transitional phase (cf. Schledermann, 1978C: 473).

\section{CONCLUSIONS}

A good deal more data must be acquired before the migration vs. in situ development dichotomy in the High Arctic can adequately be assessed. Future speculations along these lines must incorporate additional evidence of 
occupational continuity and must be able to account for the "information exchange systems" (Wobst, 1977) which maintained the obvious cultural ties between the eastern Central Arctic and the Arctic Archipelago. Continued analysis of the information collected during the 1978 season will be directed towards fully documenting the early Dorset occupation of the Crozier Strait region. The relationship between the Karluk Island localities and Independence II complexes will be examined more closely, as will the documented affinities with Eastern Arctic early Dorset components.

\section{ACKNOWLEDGEMENTS}

I would like to acknowledge the Arctic Institute of North America (with the financial assistance of the Firestone Foundation) and the University of Calgary for their financial support. My appreciation also to the Polar Continental Shelf Project for logistic support in the field. I would like to thank Dr. Peter Schledermann for his assistance in the planning stages of the 1978 Karluk Island Archeology Project. My heartiest thanks to Liza Churchill who ably assisted me in the field and who helped in the laboratory analysis of the obtained collections.

\section{REFERENCES}

ANDREWS, J. T., MCGHEE, R. and MACKENZIE-POLLOCK, L. 1971. Comparison of archaeological sites and calculated sea levels in Arctic Canada. Arctic 24: 210-228.

BARRY, R. G., ARUNDALE, W., ANDREWS, J., BRADLEY, R. and NICHOLS, H. 1977. Environmental change and cultural change in the eastern Canadian Arctic during the last 5000 years. Arctic and Alpine Research 9(2):193-210.

COLLINS, HENRY B. 1957. Archaeological investigations on Southampton and Walrus Islands, N.W.T. National Museum of Canada Bulletin 147:22-61.

DEKIN, ALBERT E. 1975. Models of Pre-Dorset culture: towards an explicit methodology. Unpublished Ph.D. dissertation, Michigan State University, East Lansing.

FITZHUGH, WILLIAM. 1974. Arctic prehistory: demographic patterns in a marginal environment. Paper presented at the Smithsonian Institution Conference, Washington, D.C.

- 1976. Environmental factors in the evolution of Dorset culture: a marginal proposal for Hudson Bay. Society for American Archaeology Memoir 31:139-169.

HELMER, JAMES W. 1978a. Evidence for an early Dorset occupation on Karluk Island: a preliminary statement. Unpublished manuscript on file at the Department of Archaeology, University of Calgary.

- 1978b. Report of the 1978 Karluk Island Archaeology Project. End of season report on file at the Archaeological Survey of Canada, Ottawa.

KNUTH, EIGIL, 1967. Archaeology of Musk-ox way. Ecoles Practiques des Hautes Etudes, Sorbonne Centre d'Etudes arctiques et Finno-Scandinaves, Contribution 5.

- 1968. The Independence II bone artifacts and the Dorset evidence in North Greenland. Folk 19:61-80.

LINNAMAE, URVE. 1975. The Dorset Culture. Technical Papers of the Newfoundland Museum No. 1.

MAXWELL, MOREAU S. 1973. Archaeology of the Lake Harbour District, Baffin Island. Archaeolgical Survey of Canada Mercury Series, Paper 6.

- 1976. Pre-Dorset artifacts: the view from Lake Harbour. Society for American Archaeology Memoir 31:58-78.

MCGHEE, ROBERT. 1971. An archaeological survey of western Victoria Island, N.W.T., Canada. National Museum of Canada Bulletin 232:157-191. 180.

1974. A current interpretation of Central Canadian Arctic prehistory. Internord 13/14:171-

1976a. Paleoeskimo occupations of Central and High Arctic Canada. Society for American Archaeology Memoir 31:15-39. 
1976b. Archaeological excavations at Porden Point, Port Refuge and Brooman Point (summer 1976). Manuscript on file at the Archaeological Survey of Canada, Ottawa.

1977. Archaeological excavations at Port Refuge and Porden Point, Devon Island, N.W.T.

(summer 1977). Manuscript on file at the Archaeological Survey of Canada, Ottawa.

1978. Canadian Arctic Prehistory. Toronto: Van Nostrand Reinhold.

and TUCK, JAMES. 1976. Un-dating the Canadian Arctic. Society for American

Archaeology Memoir 31:6-14.

MELDGAARD, JORGEN. 1962. On the formative period of the Dorset culture. In: Campbell, J. (ed.). Prehistoric Cultural Relations Between the Arctic and Temperate Zones of North America. Arctic Institute of North America Technical Paper 11:92-95.

SCHLEDERMANN, PETER. 1977. An archeological survey of Bache Peninsula, Ellesmere Island, Arctic 30(4):243-245.

1978a. Distribution of archaeological sites in the vicinity of the proposed Polar Gas Pipeline and staging areas, N.W.T. Unpublished report by the Arctic Institute of North America for the Polar Gas Project.

1978b. Prehistoric demographic trends in the Canadian High Arctic. Canadian Journal of Archaeology No. 2:43-58.

$1978 \mathrm{c}$. Preliminary results of archaeological investigations in the Bache Peninsula region, Ellesmere Island, N.W.T. Arctic 31(4):459-474

TAYLOR, WILLIAM E. 1967. Summary of archaeological field work on Banks and Victoria Islands, Arctic Canada, 1965. Arctic Anthropology 4(1):221-243.

1968. The Arnapik and Tyara Sites: An archaeological study of Dorset culture origins. Society for American Archaeology Memoir 22.

- 1972. An archaeological survey between Cape Parry and Cambridge Bay, N.W.T., Canada in 1963. Archaeological Survey of Canada Mercury Series, Paper 1.

TENER, JOHN. 1965. Musk-ox in Canada: A biological and taxonomic review. Canadian Wildlife Service Monograph No. 2.

WILMETH, ROSCOE. 1978. Canadian archaeological radiocarbon dates (revised version). Archaeological Survey of Canada Mercury Series, Paper 77.

WOBST, H. MARTIN. 1977. Stylistic behavior and information exchange. In: Cleland, Charles E. (ed.). For the Director: Research essays in honour of James B. Griffin. University of Michigan, Museum of Anthropology. Anthropological Papers 61:317-342. 